\title{
Constructive Alignment as a Means to Establish Information Literacy in the Curriculum
}

\author{
Fredrik Eriksson * \\ Lund University
}

\begin{abstract}
Constructive alignment is the pedagogical principal which connects learning goals and learning activities with assessment. Learning goals should inform the student about what they'll know once they finish the course. Learning activities is what the student needs to do to fulfill the goals. The assessment measures to what degree the student reaches the learning goals. The principal of constructive alignment permeates Swedish higher education. Regulatory documents at both national and local level talk about the importance of having a logical connection between the three parts that make out the principle of constructive alignment. But can we use Constructive Alignment as a means to establish courses in information literacy? I think we can if we align the structure of IL-courses with existing syllabus and formalize this connection.
\end{abstract}

Keywords: embedded librarianship, academic study skills, information literacy, first-year experience

\section{*Contact:}

Fredrik Eriksson

Libraries of the Faculties of Humanities and Theology, Lund University, Sweden

E-mail: ecostian@abo.fi 


\section{Introduction}

This presentation is based on a work in progress conducted at the libraries of the Faculty of Humanities and Theology (HT-Faculty) at Lund University. We are two libraries and 17 liaison librarians serving 3500 students and 500 researchers at 7 institutions.

\section{Constructive Alignment}

Constructive Alignment (CA), developed by John Biggs in 1996, is the pedagogical principal of connecting Learning Goals with Learning Activities and Assessment (Biggs, 1996). Learning goals tell the student what she is expected to know once the course is finished. Learning Activities is what the student needs to undertake to attain the learning goals. Assessment is about how well the student reached the goals that were set for her (Biggs, 2016; Elmgren \& Henriksson, 2015).

These three parts should work together as a well-oiled machinery with interlocking cogs and makes out, what I would call, the holy trinity of CA.

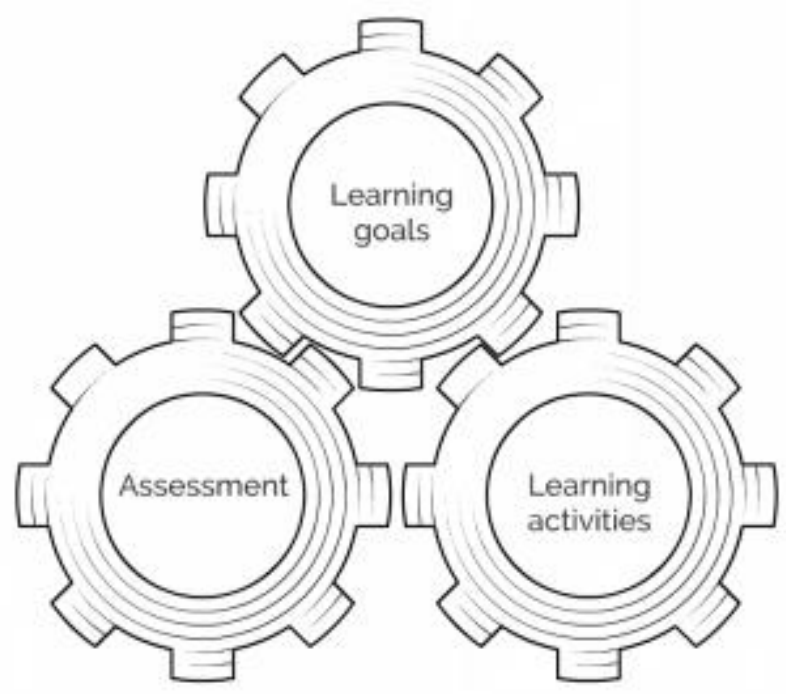

Figure 1. A simplified model of Constructive Alignment

But do we have to take CA under consideration when we develop our IL-courses? I mean, it's just a principal and we could easily ignore it. Well, there seems to be good support for it when reading through regulatory documents for higher education.

First off, the key for information specialists and librarians who give IL-courses would be to be a part of the goals for a given course. The goals set the direction for a course and underlines what's central for the students learning. Luckily, in Sweden the Higher Education Ordinance mentions the importance of students acquiring IL-skills during their time at the University (SFS 1993:100). So there is a good ground there to implement IL-related goals in existing syllabuses.

At the local faculty level where I work we find regulatory documents stating that courses should be evaluated on the basis of "... the pedagogical process in a course where learning goals, teaching activities and assessment results are in focus" (Lunds universitet, 2013).

So there seems to be a good basis for the use of CA as a framework for the establishment of IL-courses. However, just because something is formally accepted it does not necessarily mean that it is culturally accepted. For instance, we find a lot of course goals in the different course 
syllabuses that are in fact unassessable. These goals are often too abstract to actually serve as a measurement of students' abilities or as a guiding light for the students during a course.

\section{How We Work}

Working with IL we have long depended on our liaison librarians to arrange and offer courses in this. The liaison librarian tries to work closely with his or her institution to establish a good foundation for establishing our courses.

However, the ability to establish a foundation has largely been dependent on the informal relation between liaison librarian and faculty. This also means that the quality of our IL-courses is dependent on this relation. This is by no means a unique situation, it seems to be a rather common phenomena. Claire McGuiness, PhD in ILS, uses the phrase Academic Champions. An academic champion is a member of faculty who has a positive idea or concept of the library. The key for the library is to identify such a champion and use that relation as a foundation for establishing IL-courses (McGuiness, 2007). The problem with this is that there is an obvious risk when it comes to assuring quality and longevity of the IL-courses. The relation needs to be as formalized as possible.

One project that we've been working on has been to establish IL-teaching plans which is a semi-formal document describing each IL-course given by the HT-library. These teaching plans describe the IL-lecture given to each course at the faculty. It describes the progression and what is expected to be the learning outcome for the students at each level. These plans where developed independently of the actual program/course syllabus but has still proved fruitful. The plans give the liaison librarians a physical document to bring to his or her institution. It's been a stepping stone to start creative discussions with faculty on implementation and collaboration regarding IL-lectures.

But we also see an untapped potential with these teaching plans. As of now they sort of exist in a vacuum between a course syllabus and learning goals. But if we can align our plans with the existing IL-related goals of the syllabuses we can formally be an imbedded part of a course.

The work at hand was to get the group of liaison librarians to adapt to the idea of CA as a means to establish IL-lectures. A group that is used to do things independently, which meant we wanted them to also embrace CA themselves.

\section{Implementation of Constructive Alignment}

The premise here is that we have a group of liaison librarians who work independently when it comes to structure their IL-lectures. We want this group to implement CA as a framework for their lectures without a whip or carrot. In other words, we want a change in culture regarding the framework of our IL-courses. We set up a plan consisting of three steps for a culture change towards implementation of CA:

1. Knowledge - Make sure everyone is familiar with the framework and the context it exists in.

2. Process - Give time and place to process the information.

3. Implementation - Make sure there is a way ahead with the newly found knowledge.

The first step was reached by composing a document which consisted of the following four topics: 
Theory behind $C A-\mathrm{A}$ brief introduction giving the main components that make out the mechanics of CA.

Teachers day-to-day reality - A text composed by a teacher at the faculty describing the work they put into a course. How much (little) time they have with each student.

Current pedagogic paradigm - Students are expected to construct their own knowledge and be the main agent in their own learning. Instead of processing uncontextualized packages of information in a classroom they are now expected to take a larger responsibility. With this increased responsibility the students need to acquire the right tools, such as searching, finding and evaluating information.

Description of our task as IL-teachers - What is expected from us as teachers? Especially in regard to the expectation from our faculty.

The document was then sent out to all teaching librarians at the faculty with a notion that the content will be discussed at a later time.

Step two, process, was reached by creating informal discussions in small groups. We divided the librarians into groups of 4-5 and invited them to discussions in an informal atmosphere. The topic of the discussions was based on the content of the document. This strategy proved very fruitful as the discussions where long lasting and conclusions reached were right on target.

The third step, implementation, was hard to predict. But it proved easier than anticipated. A few weeks after the group discussions we had a couple of strategy days for the library. During this event a group took upon themselves to develop an action plan describing how they, step by step, align their teaching plans with existing syllabuses. The plan in itself was very simple and pragmatic, but gives us a tool to move forward with a road map in hand.

\section{The Future}

This summer we will see a full implementation of the CA-framework as a base for the development of our IL-teaching plans. The liaison librarians will make use of the action plan as a tool for implementation. The goal will be to have a fruitful alignment between our teaching plans and the existing course syllabus.

This autumn there will also be an in-house pedagogical conference at the faculty. We will be present there and present our ideas and our work towards an alignment of our work in regard to the existing syllabuses. Hopefully this will further a formalization of the work conducted by the liaison librarians at the faculty and establish a good foundation for assurance and longevity of quality with our IL-courses. 


\section{References}

Biggs, J. (1996). Enhancing teaching through constructive alignment. Higher Education, 32(3), 347-364. http://doi.org/10.1007/BF00138871

Biggs, J. (2016). Constructive alignment. Retrieved from http://www.johnbiggs.com.au /academic/constructive-alignment

Elmgren, M., \& Henriksson, A. S. (2015). Universitetspedagogik. Studentlitteratur.

Lunds universitet. (2013). Policy för kursvärdering och kursutvärdering vid HT-fakulteterna. Dnr HT 2013/183. Retrieved from http://www.ht.lu.se/uploads/media/Policy_fo__r_kursva_rdering_och_kursutva_rde ring_vid_HT-fakulteterna_BESLUT_01.pdf

McGuinness, C. (2007). Exploring strategies for integrated information literacy: From "academic champions" to institution-wide change. Communications in Information Literacy, 1(1), 26-38.

SFS 1993:100. Högskoleförordningen. 